\title{
Talent management in the South African construction industry
}

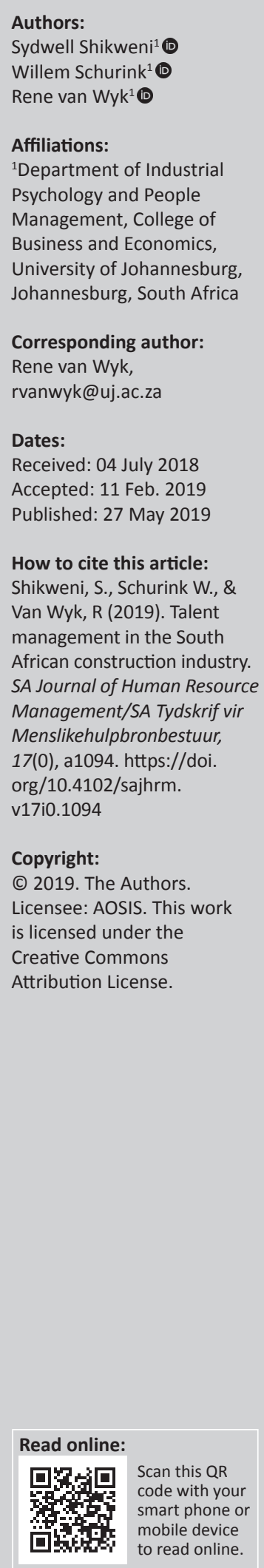

Orientation: The South African construction industry is constrained by the shortage of a skilled workforce due to global competition and insufficient graduate output. There is a need to evolve attract and retain the most valuable talent.

Research purpose: The aim of this study was to investigate talent management in a prominent South African internationally operating construction company. The objective is to develop a framework for enhancement of talent management practices.

Motivation for the study: The South African construction industry's inability to retain talent, hampers global competitiveness and productivity. Talent shortages need to be addressed at a strategic level to remain competitive.

Research approach/design and method: A qualitative research approach examined a single South African construction organisation in the Gauteng Province. Grounded theory was used to analyse data generated from interviews, participant observations and company documents.

Main findings: Firstly, talent management in the construction industry supposes mutual actions from the organisation and its talented employees. Secondly, internal enablers drive business outcomes by in alignment with a well-crafted strategy. Thirdly, a regulatory framework should acknowledge labour market dynamics and diversity. Fourthly, internal and external enablers should be taken into consideration. Finally, effective implementation of talent management practices yields talent sustainability and competitiveness.

Practical/managerial implications: The two conceptual frameworks developed indicate: (1) key factors that play a role in talent management, and (2) the interface between talented employees and the organisation.

Contributions/value-add: The findings provide two proposed frameworks that could guide leadership to devise an enabling global competitive talent management environment in the construction industry.

Keywords: talent management; talent attraction; talent development; talent retention; South African construction industry; talent management framework; qualitative research; thematic analysis.

\section{Introduction}

The construction industry is one of the primary pillars of economies around the world (Fapohunda \& Chileshe, 2014; Oyewobi, Windapo, \& James, 2015; Sawhney, Agnihotri, \& Paul, 2014; Xue, Zhang, Yang, \& Dai, 2014). Within the construction industry, talent management practices are characterised by ongoing mobilisation and demobilisation of people at different stages of construction projects (Mitchell, 2011). Mobilisation relates to the activation of resources for a specific project, and demobilisation entails deactivation of resources at the construction site (Business Dictionary). The number of employees in a similar environment increases or decreases to meet the demands of major project work. There are a number of challenges confronting the industry in relation to talent management, such as the slowing down in infrastructure projects because of economic pressures (Coulson-Thomas, 2012); the often remote location of key positions (Böhmer \& Schinnenburg, 2016) and the ongoing war on talent as a result of talent shortage (Böhmer \& Schinnenburg, 2016, Swailes \& Blackburn, 2016; Worrall, Harris, Stewart, Thomas, \& McDermott, 2010). Consequently, the industry finds it difficult to attract and retain talent. The ability and flexibility to meet these challenges are key to ensuring successful talent management in construction (Boshard \& Louw, 2012). 


\section{Construction industry: The South African perspective}

The construction industry contributes significantly to stimulating employment and growing the South African economy (Oyewobi et al., 2015). The contribution of the construction industry to the growth domestic product (GDP) figures has consistently exceeded $8 \%$ since 2007 . The total projected investment in the infrastructure for the period between 2012 and 2017 was approximately US\$500 billion. The industry employs over 1.4 million people in the country, approximately $8 \%$ of the total formal employment sector and about $17 \%$ of the informal employment sector (Human Capital and Labour Report, 2017).

The construction industry in South Africa is relatively large and includes both building and civil engineering, varying between small to mega infrastructure projects (Burger, Verster, \& Zulch, 2015). Construction, by its very nature, is a project-based and service-enhanced industry comprising multiple stakeholders with varying expectations (Xue et al., 2014). In addition, the industry has to deal with complex projects, fragmented structures, and supply chain relationship complexities between contractors, suppliers, clients and communities (Emuze \& Smallwood, 2014; Xue et al., 2014). The stringent transformation imperatives imposed by Broad-Based Black Economic Empowerment (BBBEE) necessitate organisations to align to this acceptable business practice. In addition, it is important that the industry aligns to legislative requirements such as the Basic Conditions of Employment Act and the Employment Equity Act administered by the Department of Labour, among others. The most common enforceable areas include pay equity (Bussin, 2015) and a workforce profile representative of the demographic make-up of the country across different occupational categories. Non-compliance to equity targets could result in substantive fines and discriminatory practices through the Council for Conciliation, Mediation and Arbitration (CCMA) and Labour Court (Kapoor, 2011).

Although the organisations in the industry are driven by the need to deliver on their infrastructure projects, they also have to make a profit to ensure sustainability. For the construction industry to benefit from projected growth, it is essential to develop an effective talent management framework. It is important that a talent management approach is used that takes contextual factors into consideration to yield better results (Dhanabhakyam \& Kokilambal, 2014).

\section{Talent management trends}

The existing knowledge on talent management is discussed from Ramaiah and Raut's (2014) perspectives, namely: (1) skills shortage, (2) ageing workforce, (3) generational mix, (4) talent loyalty, (5) talent pipeline, (6) technological advancement, (7) global talent marketplace, (8) global talent pool, (9) talent mobility, (10) talent destinations and (11) employer branding.

\section{Skills shortage}

The scarcity of talent is evident across various industries, and is a global phenomenon (Manpower Group, 2013), serving as a threat to viability (Böhmer \& Schinnenburg, 2016). Many organisations continually struggle to source and place appropriately qualified and experienced talent (Tarique \& Schuler, 2012). Talent shortage forces organisations to purposefully embed talent management practices, and even revert to poaching and headhunting (Gundling, Caldwell, \& Cvitkovich, 2016). Clearly, the supply of talent is not adequately meeting the current demand, and this may continue to be a long-term challenge (Kapoor, 2011). A balance of initiatives needs to be designed to meet the shortto medium-term needs. A talent management framework, aligned with an organisation's strategy, could address these short- and medium-term needs (Manpower Group, 2015).

\section{Ageing workforce}

Organisations experience an increased talent shortage with an ageing workforce (Minneci, 2015; Ping, 2011). On the one hand, developed countries have population figures that are shrinking, with ageing populations (Tarique \& Schuler, 2012). On the other hand, developing economies have a growing population which is becoming younger. It seems essential to plan around replacing the employees who are nearing retirement age with a younger generation of talent (Thunnissen \& Van Arensbergen, 2015). The older and the younger generation exhibit varied traits and expectations, making it challenging to facilitate the transfer of skills from one generation to another (Tarique \& Schuler, 2012). Although it may not pose an immediate threat, there is a need to address the ageing workforce before it becomes an urgent priority. This challenge provides an opportunity to closely look at their respective work values, attitudes and career expectations to ensure appropriate alignment and talent management interventions ( $\mathrm{Ng} \&$ Parry, 2016).

\section{Generational mix}

Today's workplace has a new reality of multiple generations comprising the millennials, generation $X$, baby boomers and the silent generation (Holt \& Seki, 2012; Ng \& Parry, 2016). Despite the high rate of unemployment more affecting the youth, there is a noticeable increase in new entrants into employment. Price Waterhouse Coopers's (2011) prediction is that the global workforce will comprise $50 \%$ millennials by 2020 and about 75\% is projected by 2025 (Herbert, 2016). Taking a closer look at the millennials who are fast entering the world of work, it can be inferred that they differ vastly compared to other generations. Millennials value a work environment characterised by transparency, flexibility and work-life balance and make career decisions based on these and related needs (Alkire, 2014; Downs, 2015). Does this mark the end of loyalty as we traditionally know it? Employers seem to be aware of this truth as they get to know millennials who freely express their needs when they enter an organisation. Given the extent of awareness of this new reality, it would be a missed opportunity if organisations are not reviewing the policies and processes necessary to 
successfully navigate through the challenges cropping up in regard to recruitment and retention of skilled personnel (O'Donnell, Karallis, \& Sandelands, 2008). It should also be noted that the global-mindedness of millennials seems to make them more inclined to accept international assignments (Alkire, 2014).

\section{Talent loyalty}

Because of high levels of loyalty in the past, employers did not pay much attention to talent management. However, the era of high levels of commitment seems to be fast fading away. It is now an acceptable norm to have multiple employers with less tenure (Caplan, 2014). People frequently change jobs, they are more sensitive to an organisation's culture and lifetime employment seems to be consigned to the past (Ratten \& Ferreira, 2016). Employees' loyalty as measured by, among others, long tenure has been replaced by loyalty when it lasts. The employees may be loyal for as long as they are with the organisation, but such loyalty can change instantly. New ways of working and performance standards empower employees to see value in the organisation, which may lead to loyalty and voluntarily returns (Aggarwal \& Bhargava, 2009). Workers today frequently change jobs or move across employers and occupations. It would seem the power has shifted from the employer to employees taking an active role in managing their own careers (Tarique \& Schuler, 2012).

\section{Talent pipeline}

Perhaps more than ever before organisations need a talent pipeline flow as a lifeblood for the organisation (Hirsh, 2014). It is certainly fundamental for the sustainability of an organisation. Identifying and developing young talent is one of the ways to create the talent pipeline needed in organisations. This requires a robust approach to integrating talent development as part of the organisation's strategy with leadership taking an active role as talent managers through mentorship, coaching facilitating job rotation and peer support (McGettingan \& O'Neill, 2009). In addition, the integration of labour market dynamics, the economic outlook and higher education institutions are necessary to foster collaborative efforts in developing and growing the talent pipeline (Leon \& Uddin, 2016; Sawhney et al., 2014).

\section{Technological advancement}

Technological solutions in workplaces are important as these bring about a number of benefits. In managing talent, systems are required to enable seamless solutions by employees and management. The employment landscape has changed and will continue to evolve owing to technological solutions available in the market (Manpower Group, 2015). Trends suggest that the future of work will be characterised by virtual teams; employees' interaction in cyberspace and social networks; flexible working hours; remote workstations and contingent workers (Hoek, 2016). For example, employees will work for multiple organisations (Tarique \& Schuler, 2012). The implementation of talent management cannot be divorced from integrating appropriate tools for enabling intelligent analytics, instant reports generation, efficiencies and reduced cost.

\section{The global marketplace}

Paying attention to talent management imperatives is no longer an option but should lead to a competitive advantage (Liu \& Pearson, 2014). Both developed and developing economies compete for the limited pool of talent available. Global talent movements place talent management high on the agenda. These movements contribute to the knowledge and practice of talent management and, in turn, to the economic growth and the overall competitiveness of many nations (Silvanto \& Ryan, 2014). The fierce competition for talent on a global scale is centred on the economic viability of both developed and developing countries (Alkire, 2014; Eilo, Yu, Tam, \& Loek, 2016), thus exacerbating at a higher scale prevalent talent shortages (Ewerlin \& Süß, 2016). The need for talent at leadership level has recently become urgent (Hassanzadeh, 2015).

\section{Talent mobility}

The rise of talent mobility is traceable to the developments relating to internationalisation, globalisation, and multinational entities and associated technology (Alkire, 2014; Nilsson \& Ellström, 2012; Sambartolo, 2015). Global talent management practices require organisations to devise more innovative strategies to attract talent as well as policies which are suitable for cross-cultural environments (Ratten \& Ferreira, 2016). It is likely that talent mobility may be a result of the declining trust between employer and employees (Böhmer \& Schinnenburg, 2016). Several organisations are considering geographic expansion as a way in which to grow the market and ensure sustainability (Gundling et al., 2016). Talent mobility has increasingly heightened the importance of diversity and inclusiveness (Silvanto \& Ryan, 2014), in the context of global talent management (Ruël \& Lake, 2014). Even though global business leaders seem to recognise the need for a global talent intelligence, it seems that some of the challenges exist in developing and implementing the required talent strategy, given the complexity involved (Gundling et al., 2016). Based on their experiences, global leaders take a lead role in the process of coordinating talent exchange (Ratten \& Ferreira, 2016). Manpower Group (2015) report that $71 \%$ of the CEOs actively search for talent in various geographic locations, noticing that talent mobility is a major concern.

\section{Geographic destinations}

As it is evident that competition for talent is not confined to a particular industry or local market, then which are the destinies worth noting? Multinational organisations, in particular, compete worldwide for the best talent within their local geographies and in international geographic areas (Alkire, 2014). The United Kingdom, Greece, Italy, Spain and Portugal are among the attractive talent destinations (Minneci, 2015). 'Multiethnic cities such as London, Sydney, Toronto, Paris, 
New York and Dubai' (Silvanto \& Ryan, 2014, p. 112) are also some of the preferred destinations. The talent flow in and out of the United Kingdom has revealed that engineers are attracted, in the main, by best offers which meet their talent specifications; the scientists and academics draw their interest in research and professional development opportunities, while entrepreneurs are more attracted by market conditions and more favourable and less restrictive regulatory environments. In South Africa, the number of people who emigrate annually, particularly at skilled levels, is a great concern. According to the Human Capital and Labour Report (2017), about 47000 professionals emigrated in 2015 alone, with the majority of them relocating to the United Kingdom.

\section{Branding strategy}

Talent management draws its strength partly from a strong brand presence (Ramaiah \& Raut, 2014). The link exists between a strong brand and the ease of attracting and retaining talent. Most organisations with a strong brand image report that they have a large number of prospective candidates in their online recruitment portal in the queue for potentially securing employment with the company. Paying attention to intangible qualities and to the strength of the organisation and the country is imperative for brand image. The intangible qualities include, among others, lifestyle, freedom, intellectual stimulation, acceptance, tolerance and immigration policies. Countries with these intangible qualities and seamless immigration policies are more successful in attracting the best of talent (Silvanto \& Ryan, 2014). In addition, the emerging markets are generally perceived to be less attractive than the developed markets. More branding is required to heighten the appeal of emerging markets, especially among millennials who are particular about brands in making career decisions (Alkire, 2014). In view of the wide variety of career choices which young people are facing, it is important to brand engineering and construction careers as attractive (O'Donnell et al., 2008). The organisation's brand image is based on how it improves its appearance in the public domain (Manpower Group, 2015), with an inclusive imperative of diversity to attract the right talent (Holt \& Seki, 2012).

\section{Talent management assessment in South Africa}

The Global Talent Competitiveness Index 2016 ranks South Africa at 67th overall out of 118 countries (INSEAD, 2016). The Manpower Group (2015) reported vital ranking statistics for South Africa relative to other countries focusing on talent attracting, talent retention, skills and competence. In attracting talent, a score of 53 out of 138 countries has been achieved. Although the country performed well on the attraction scale, it is worrying that the score of 34.55 out of 100 , ranking 101 out of 118 countries, indicates a dismissal performance in retaining talent. The worst of all the indicators is the compensation and hiring practices, in which the country was placed 135 out of 138 countries. With reference to the difficulties in filling positions, more than $50 \%$ of the organisations surveyed reported negative environmental or market conditions, over $47 \%$ reported a lack of technical competencies, $46 \%$ reported lack of applications for particular positions, 30\% reported a lack of specific industry qualifications and skills and $26 \%$ reported a lack of suitable work experience (Manpower Group, 2015). In addition, remote and undesirable locations, expectations and demand for higher remuneration, an absence of people skills, lack of drive and motivation were also raised as reasons why organisations find it difficult to fill certain key positions (Manpower Group, 2013). South Africa's unemployment rose to $27.1 \%$ in the third quarter of 2016 relative to $26.6 \%$ in the second quarter of the same year (Statistics SA, 2017). Youth unemployment, in particular, is of growing concern in the country.

The above statistics require organisations in the country to invest significantly in talent management. The cost of expatriates in respect of remuneration, relocation and attrition makes it extremely challenging to demonstrate return on investment (Herbert, 2016; McNulty \& De Cieri, 2016). It is important that organisations in the construction industry make adequate provision for talent and manage talent within the budget parameters (Burger et al., 2015). The economic pressures for resource efficiency are driving the need to manage cost and streamline resources, thus creating the challenge of ensuring sufficient budget for talent management (Sahay, 2015).

\section{Talent management in the construction industry: Key skills required}

Construction projects often involve a significant diversity of multiple participants, each with a set of skills required to deliver on the goals of the project (Xue et al., 2014). Construction site managers should possess leadership skills, understanding of the legal requirements, a range of technical and blended business skills (Fapohunda, 2014) and Project Management Institute (PMI) Construction extension to the Project Management Body of Knowledge, commonly known as PMBOK (Fapohunda \& Chileshe, 2014). It is critical to have effective team leadership to ensure the success of a construction project, with leadership development, and problem-solving skills playing a vital role (Senaratne \& Samaraweera, 2015). The core skill of electrician or electrical technicians enables career development towards management in the construction disciplines, which is in short supply (McGettingan \& O'Neill, 2009). The Construction Sector Skills Plan (SSP) maps out the comprehensive plan for the demand and supply of skills in the industry. Specific focus is placed on NQF-aligned skills programmes, and completion of candidacy registration programmes post academic qualifications is one of the priority areas for the Construction SETA. The completion of the candidacy programme enables the professionals, particularly architects, engineers and quantity surveyors and estimators, to register with relevant professional bodies as one of the key requirements to practice (CETA SSP, 2017).

\section{Purpose}

The purpose of this qualitative study was to investigate perceptions of talent management practices and actual practices in a specific organisation within the construction industry. 
The following questions were formulated:

- How do senior and junior managers perceive the current talent management in the construction industry?

- What are seen as enablers of talent management practices in the construction industry?

- What are regarded as barriers to talent management practices in the construction industry?

- What support mechanisms are in place to support the effective implementation of talent management in the industry?

- What talent management insights may be gained from organisations outside of South Africa?

\section{Research method}

A qualitative research approach was adopted for the study to (1) explore a particular aspect of reality as identified by the researcher (Creswell, 2003), and to (2) gain better insight into people's views (Marvasti, 2011). Personal interviews provide opportunities to explore participants' insights, to offer a holistic picture of perceptions (Branthwaite \& Patterson, 2011), by illuminating the circumstances (Bogdan \& Biklen, 1992), as a result of rich information (Guercini, 2014).

In line with Bloomberg and Volpe (2008, p. 80), the authors felt a case study best served to gaining 'an in-depth understanding' of talent management in the construction organisation. Case studies are used in a wide variety of disciplines to acquire an understanding of a focused situation to contribute to theory (Yin, 2003). To explore perceptions related to talent management practices in the organisation, we opted for a single case, namely, a construction and engineering projectbased organisation located in the Gauteng Province. The setting reflects Mitchell's (2011) features of being projectdriven, specialisation in services and work characterised by high-risk, high-reward and low job security.

To facilitate in-depth engagement, a relatively small number of participants were selected (Branthwaite \& Patterson, 2011; Mariampolski, 2011). We used purposive convenience sampling to select research participants who had first-hand experiences of organisation talent management (Bloomberg \& Volpe, 2008; Rosenthal \& Rosnow, 2008). Four were identified: two males at senior management and two females (one at middle management and one at junior management level). These four individuals functioned at a level where implementation of talent management practices is executed.

It is extremely important that appropriate data collection methods are used to produce data which will inform the issues under investigation (Wu \& Patel, 2015, p. 98). Regarding the case study, Farquhar (2013, p. 2 of 22) writes: 'Case study research is characterised by multiple data sources, often consisting of different data collection techniques'. Therefore, we applied the following data collection methods: (1) combination of semi-structured and unstructured interviews, (2) participant observation and conversations, and (3) reviewing of company documents. Grounded theory was used to code information through open coding, axial coding and selective coding (Bryman \& Bell, 2007).

\section{Ethical considerations}

The study was aligned to the ethical code and guidelines of the College of Economics and Management of the University of Johannesburg. Participants signed informed consent to take part in the project voluntary and that information would be handled confidentially. Participants were introduced to the background of the study, the aims and objectives and the estimated time of the interviews. Participants were ensured that they could withdraw at any time without any negative consequences. With informed consent participants were assured that the research would be based on sound methodological principles of care, integrity, professionalism and confidentiality. Informed consent implied: providing assurance to the participants that: (1) they should feel free to make an independent decision and to either participate or withdraw without fear of negative consequences, (2) there would be a cultural sensitivity towards their background, (3) interviews would be conducted in a convenient and comfortable location, (4) they would be given the opportunity to express their thoughts. Interviews were transcribed and kept secured by being password protected. The data will be kept for a period of 5 years after graduation, after which it will be destroyed.

\section{Findings}

Analyses of the interviews provided two conceptual frameworks that are depicted in Figures 1 and 2. Figure 1

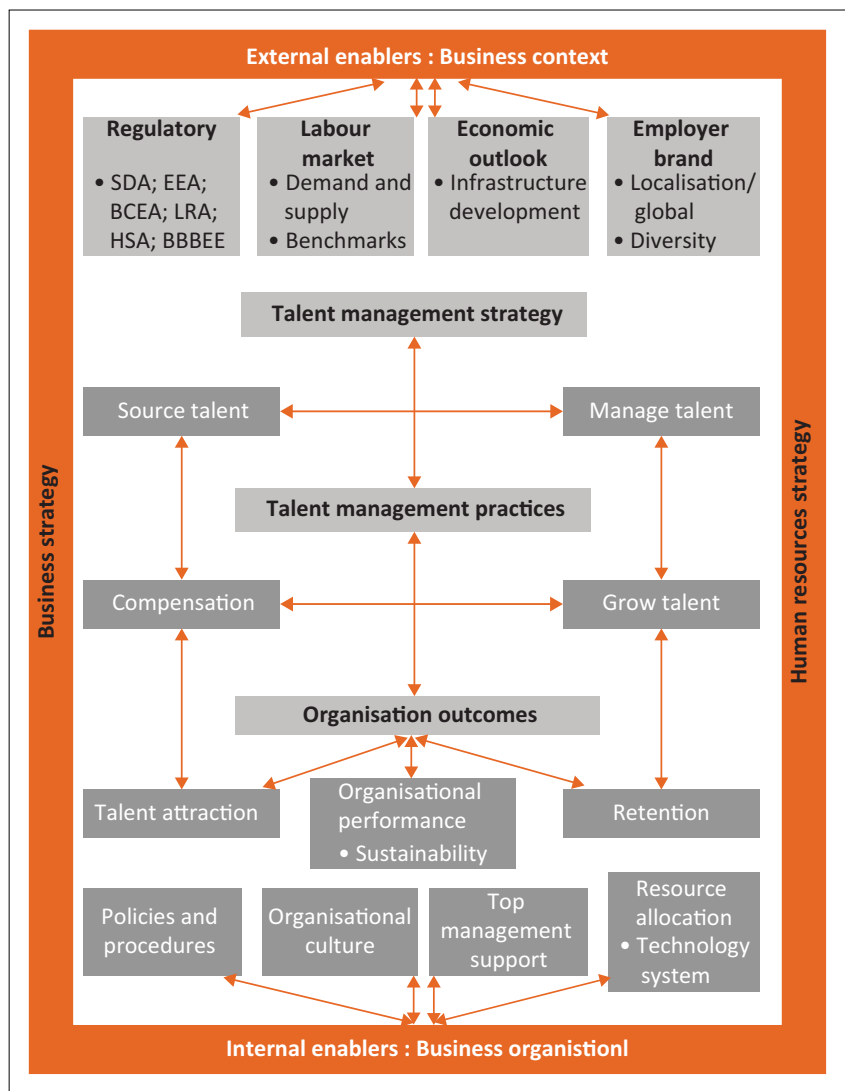

FIGURE 1: Talent management framework: attraction and retention. 


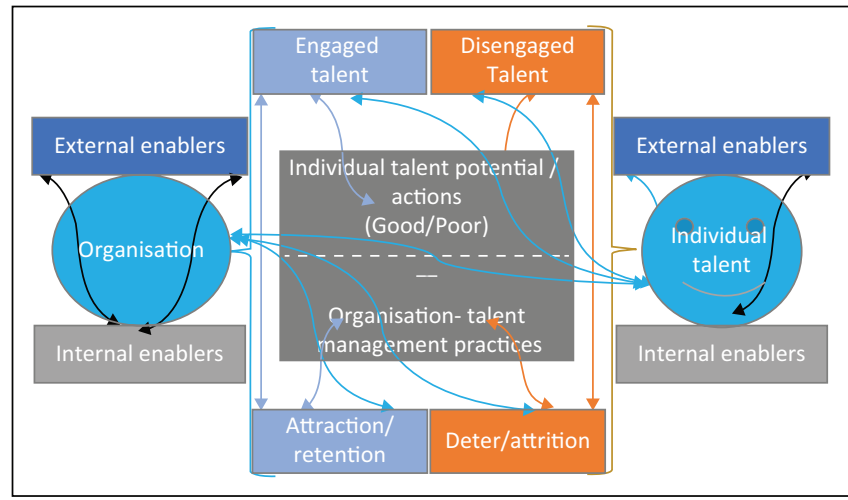

FIGURE 2: The interface between talented employees and the organisation.

provides a holistic explanation of talent management processes in the organisation studied. The framework comprises three broad focal areas, namely, talent management strategy, talent management practices and talent management organisational outcomes.

Figure 1 comprises three broad focal areas, namely, talent management strategy, talent management practices, and talent management organisational outcomes. It indicates that the effectiveness of the organisation's talent management may broadly be assessed in terms of talent attraction and retention, in line with desired organisational outcomes. The talent management framework of Figure 1 links the organisation's talent management strategy to its human resources and business strategy. It is imperative that the framework is anchored in the ability to deliver on its business strategy. The purpose of the framework is to attract and retain talent that is aligned with the strategic objectives and envisaged business performance.

The interactions that take place in the talent management framework (Figure 1) led to the development of Figure 2 that explains the interface between talented employees and the organisation.

Figure 2 illustrates that organisational talent management comprises various internal and external factors. Although embedded within one organisation, it is not possible to divorce the effective management of talent in this organisation from external business environment, including broader labour market dynamics. The alignment of talent management to both global business and existing regulatory frameworks is key to sustaining the organisation's competitive advantage. In addition, the organisation has internal processes and policies in place that guide the implementation of its talent management practices (sourcing, management, growth and compensation).

\section{Discussion}

The functional operation of the talent management framework (Figure 1) and the interface between talented employees and the organisation (Figure 2) will be discussed sequentially.
The talent management framework in Figure 1 depicts concepts of importance for the development of a talent management strategy. The framework is underpinned by an appreciation of the impact of external environmental factors on internal organisational talent management practices. A useful way in which to appreciate external enablers is to understand and align them with relevant legislation and to understand labour market dynamics of the supply and demand for talent. Both the country's economic outlook and the organisation's budget allocation for infrastructure projects play a role in predicting the viability of construction projects. These enablers allow the organisation to appropriately position itself to award these projects and ensure sufficient talent availability. Boshard and Louw (2012) emphasise that flexibility in meeting these challenges is a key factor in successfully managing key talent in the construction industry.

The framework emphasises the need for the organisation to be deliberate in its brand image to become an employer of choice. This is especially important, taking into account the complexity of projects and supply chain relationships involved (Emuze \& Smallwood, 2014; Xue et al., 2014). As the organisation operates on an international platform, paying attention to diversity and inclusion may assist in enhancing the brand image while also stimulating attraction and retention of talent. An organisation's talent management is enhanced by its position in terms of enabling policies and procedures. This is especially important in the light of the complexities that the supply chain relationships consist of (Emuze \& Smallwood, 2014; Xue et al., 2014). The test of the effectiveness of its policies and procedures focuses on implementation policies in creating a talent culture. Sound organisational policies and procedures enable businesses to source, manage, grow and reward talent.

As outlined in Figure 1, the framework emphasises four practices that steer talent management in line with organisational strategy, namely, sourcing, managing, growing and compensation.

\section{Talent sourcing}

It is widely accepted that attracting the most suitable candidates enhances an organisation's ability to deliver excellent results. Sourcing talent, in the context of the construction industry, should focus on building an employer value proposition (EVP) and an organisational brand image (Meyer, 2016). This would imply the removal of barriers to internal talent pools and external talent accessibility. The removal of barriers for talent is also entrenched in the Employment Equity Act, No. 55 of 1998, which promotes organisations to develop and promote talent from underprivileged backgrounds in terms of gender, age and race. Organisations should, thus, purposefully manage talent to fulfil short-, medium- and long-term demands (Kapoor, 2011). In addition, recruiting quality candidates supports retention as the right match is likely to enhance employees remaining with the organisation (Sahay, 2015). 


\section{Performance management}

There are four activities involved in the performance management cycle, namely, defining performance goals, managing performance, reviewing feedback and performancebased decisions (Swanepoel, Erasmus, Van Wyk, \& Schenk, 2003). Performance outcomes affect employee compensation, growth prospects and development, while effectively managing performance enhances role clarity, communication, feedback and merit-based compensation. Performance ratings serve as an input into the talent review process. Sound performance standards may even lead to loyalty to the organisation (Aggarwal \& Bhargava, 2009). As Shikweni (2010) points out, the way performance is managed influences an organisation's success or failure with regard to attracting and retaining talent.

\section{Growing talent}

Ongoing talent development impacts positively on commitment. It is imperative that the organisation understands the set of knowledge and skills it requires and develops interventions to close any gaps as a way of looking after talent (Stewart, 2016). Developmental opportunities should be used to develop the required skills, assist talent to better fulfil their roles and, by means of a blended approach, focus on the future needs of the organisation. As Meyer (2016) points out growing talent needs to be personalised through developing a personal development plan, and by offering suitable learning programmes to allow talent to demonstrate proficiency and mastery of the competencies obtained through various forms of learning.

\section{Compensation}

Talented employees tend to be more concerned with better compensation than their less talented counterparts. As Kock and Burke (2008) emphasise, compensation relates to practices such as competitive remuneration and the alignment of reward and benefits. With regard to performance, it plays a key role in ensuring a continued supply of talent and retention (Dubey \& Gunasekaran, 2015). Chew and Chan (2008) indicate that remuneration and recognition have a positive impact on commitment, and also stimulate intention to remain with the organisation. Employees are inclined to stay with an organisation when they experience acknowledgement of their efforts, contributions and performance. The fair administration of compensation differentiates poor performers from top performers and enhances the employment relationship (Kock \& Burke, 2008).

\section{Organisational outcomes}

There are several outcomes associated with talent management practices. Chew and Chan (2008) describe three perspectives leading to specific outcomes: (1) the universal, (2) contingency, and (3) the configuration approaches. The universal approach suggests identifiable best practices which, when well executed, may lead to organisational performance, while the contingency approach suggests that various practices may be contextualised to different settings and strategies, which, in turn, may lead to desirable organisational outcomes. The configuration approach advocates a good fit between the practices and strategies that improve organisational performance (Chew \& Chan, 2008).

The execution of the framework is mainly dependent on the calibre of talent and how the talent interfaces with the organisation. In developing the framework, the context of the organisation and the talented individuals were considered. The framework was developed on the premise which considers its external and internal enablers in stimulating potential talent management. The organisation needs to drive the initiatives to stimulate talent potential. When the initiatives are not well received, the organisation fails in its endeavour to stimulate talent. Both the organisation and the talent stand to gain when initiatives and individuals' expectations are aligned.

Figure 2 demonstrates that talented individuals with potential area are better placed to lead the organisation. Stimulating talent through practices and actions or the absence thereof influences an organisation's success or failure in managing its talent. When talented individuals enter the organisation, their potential may both be developed to their benefit and to the benefit of the organisation or talent potential may remain underutilised. Underutilised talent results in stagnation or deterioration with the concomitant detrimental effect on the organisation as well as on the individual.

As a collective endeavour, talent management is premised on dependence, interdependence and the mutual required practices and actions of the organisation and its talented employees. Leaders have the responsibility to determine strategy and prevent apathy and to create an enabling environment to allow the organisation's talent to thrive (McGettingan \& O'Neill, 2009). The organisation's talent management can be influenced by internal processes that we refer to as internal enablers and the external environment referred to as external enablers.

\section{Internal enablers}

In this study, driving business results, policies and procedures, leadership, exclusive and inclusive approach and technology have been identified as the most important internal enablers.

\section{Driving business results}

To achieve results, big-picture thinking is required in relation to the organisation's talent management strategy, its processes, its policies and its organisational culture. It was clear from the study's findings that, in relation to its current and future projects, the organisation where the study was conducted was not always prepared to meet the demand for talent and its leadership pipeline model was not facilitating talent. Consequently, the flow of its talent was not at the pace that was required. In fact, internally its talent supply was 
relatively low compared to what it was capable of producing. Kapoor (2011) warns that a lack of strategic leadership in talent management may lead to long-term predicaments.

\section{Policies and procedures}

There were challenges in respect of the organisation's policies and procedures regarding its talent management. These issues were not, however, related to poorly constructed documents, but to the way in which the guidelines were communicated and administered. Organisational policies and procedures need to be in place when challenges arise (O'Donnell et al., 2008). Policies should also support a crosscultural environment (Ratten \& Ferreira, 2016).

\section{Leadership}

An organisation's leadership should play a key role in ensuring that its internal processes, including those for talent management, are aligned. Accountable senior leaders are actively involved in the agenda in respect of talent management in an organisation. Leadership skills should be from an umbrella of expertise that consists of a blend of financial, legal, technical (Fapohunda, 2014) and problemsolving skills (Senaratne \& Samaraweera, 2015). The organisation in the study did not have a human resources director and operated for many years without a dedicated recruitment manager. Consequently, efforts by the leadership, line managers and practitioners, key to administering its talent management practices, were often not aligned.

\section{Inclusive versus exclusive approach}

The alignment between the individuals' talent aspirations and those of the organisation should accord with job satisfaction. In addition, attracting talented individuals to organisations should minimise talent turnover, ensure continuity and reduce hiring costs. This usually means that demonstrating a return on investment becomes less of an effort. Furthermore, the benefits accruing from increased performance, enhanced organisational output and customer satisfaction improve the organisation's image. The findings indicate that the organisation had adopted an exclusive talent management approach, focused only on the potential of its leadership and not on that of all its talented employees (an inclusive approach). Consequently, many talented employees at other levels and in functional areas core to the organisation remained underutilised.

\section{Technology}

Technology has recently become a key factor in talent management, in particular because it provides several platforms and tools which appeal to this younger generation (Sahay, 2015). The organisation demonstrated inadequate technology in supporting its talent management practices. For example, performance management was not fully automated, while, at the time of the study, the organisation had yet to invest in e-learning to assist the development and growth of talent.
Having discussed the internal enablers, it is equally important for the organisation to align with the external enablers identified in this study.

\section{External enablers}

Four external enablers relevant to the organisation are labour market, brand image, location and working conditions, and demographics.

\section{Labour market}

Finding and employing individuals with appropriate talent, managing, growing and compensating them should be aligned with broad labour market dynamics. The labour market suggests that the prevailing skills shortage is an issue of major concern and that it extends beyond the context and boundaries of both the organisation in question and the construction industry in general. In fact, it is a global phenomenon. There is a shortage of talent in the construction industry, particularly in the technical, engineering and related disciplines. Leon and Uddin (2016) and Sawhney et al. (2014) suggest that collaboration be fostered with higher education institutions in growing a talent pipeline.

\section{Brand image}

Organisation's perceived value in terms of its brand value is key in attracting the diverse talent and then retaining such talent (Ramaiah \& Raut, 2014). Although historically strong, the recently imposed penalties by the Competition Commission for collusion had damaged the organisation's brand image. The brand image helps to attract the best talent as individuals wish to associate themselves with organisations with superior brands and disassociate themselves from those which have not established themselves or whose brand images are tarnished. It is important to remember that an organisation's alignment with its external environmental impacts positively on the organisation itself and, ultimately, on its brand image (Ramaiah \& Raut, 2014).

\section{Location and working conditions}

The study found that the remote locations of construction projects and the negative working conditions seemed to be a major barrier to attracting the best talent. Working conditions are often considered to be hazardous. In addition, employment contracts often oblige talent to be mobile when required to work in remote locations and offshore and this was unsettling.

\section{Demographics}

In its pursuit of talent management, the organisation was under pressure to balance its workforce demographic make-up profile to ensure that it was representative of that of the country. In fact, this was often included in the organisation's contractual obligations with its clients. In particular, the Employment Equity Act No. 55 of 1998 required the company to provide employment opportunities to previously disadvantaged South Africans, including those 
with disabilities. The BBBEE requirements, particularly management control and skills development elements of the Construction Sector Codes, necessitate focused attention on creation of black talent pipeline.

It is expected that a thorough understanding of both the internal and the external enablers will lead to effective talent management practices.

\section{Talent management practices}

The organisation's talent management practices have been reviewed and broadly categorised as sourcing, management, growth and compensation.

\section{Sourcing}

The continued mismatch between the supply and demand of talent was forcing the organisation either to appoint less capable talent or to look outside of the country. The study found that the organisation tended to use traditional methods of sourcing talent, including CV screening, shortlisting, interviews and reference checks. However, sourcing strategies in the labour market have evolved. It would appear that the best method is to tailor the sourcing strategies for each different generational grouping based on the group's respective unique characteristics. However, the organisation in the study was yet to use a tailored sourcing approach and to exploit social media platforms. A sensitivity is needed towards a workforce consisting of multiple generations (Holt \& Seki, 2012; Ng \& Parry, 2016). It is especially the specific needs of millennials that need to be taken into consideration (Alkire, 2014; Downs, 2015), as they should be forming 75\% of the workforce by 2025 (Herbert, 2016).

\section{Management}

Performance management starts with goal setting which is aligned with the broader organisational goals and culminates in the performance review. It was clear that there was a need for consistency in the performance reviews conducted by the organisation. The performance management reviews were scarcely ever completed by the set timelines. In addition, there was no management of the consequences of noncompliance with the performance reviews. It seemed that completion of the performance reviews speeded up close to the financial year-end because of the threat of no performance rating on the system leading to no bonus pay. This could potentially lead to skewed performance ratings in which disengaged employees were often not identified. Unfair performance appraisal would inevitably lead to disgruntled employees (Aggarwal \& Bhargava, 2009). Performance management outcomes led to key decisions in relation to talent, for example, promotion, development and compensation, which were not necessarily fair.

\section{Growth}

It has been established that talented individuals value opportunities for learning and for personal and professional growth. Talented individuals prefer working environments where there is a trust relationship with their line managers, empowerment, growth prospects and work-life balance. Career security should be fostered through learning and career development. Growing talent is one of the key practices that has been recognised for its impact on engaging talent. Leon and Uddin (2016) and Sawhney et al. (2014) suggest that joint partnerships are formed with educational institutions in securing future talent requirements. It is a concern that in this study, it was found that talent development was not prioritised and, consequently, very limited budget provisions were made for it.

\section{Compensation}

Organisations review their compensation practices with a view to remain competitive in the global talent market (Maloa \& Bussin, 2016). Attractive compensation structures attract talented individuals' drive to performance and productivity (Fapohunda \& Chileshe, 2014). Compensation plays an important role in performance management as motivational theory links performance outcomes to incentives. The study established that the business's profitability paved the way for the organisation to reward its employees by means of incentives. However, the organisation's remuneration and incentive payouts process for employees are not transparent and the alleged disparities remain a source of tension between the employer and the employees. The organisation had been forced by the Department of Labour to undertake an exercise to address these disparities as part of the equal pay for work of equal value legislative requirement. It is no surprise that the Global Talent Competitiveness Index 2017 ranks South Africa's compensation and hiring practices as 135 out of 138 countries (INSEAD, 2016).

\section{Organisational outcomes}

The challenge an organisation faces regarding talent is how to attract talent and then how to keep such talent sufficiently engaged to remain with the organisation. Limited career growth opportunities were cited as a major reason why people decided to leave the organisation. At the time of the study, the organisation had not found alternative strategies such as meaningful work, job enrichment and work-life balance, to retain its talent. This meant that its organisational structure was becoming flatter, and the emergence of a matrix reporting structure was rising. However, the organisation did respond adequately to the need to counter turnover costs, the loss of organisation knowledge, interrupting client service and so on, resulting from a high staff turnover which was over $15 \%$. Organisations should especially be sensitive that fierce international competition could jeopardise talent management practices (Alkire, 2014; Eilo et al., 2016; Ewerlin \& Süß, 2016).

\section{Practical implications}

The findings of the study have implications for talent management and practices in the construction industry.

\section{Theory}

Firstly, the substantive theory the study offers for managing talent in the construction sector has expanded existing 
knowledge by integrating first-order concrete experiences with abstract, scholarly concepts derived from the literature, thus illuminating several interrelated concepts or building blocks in respect of talent management theory. Secondly, because retaining key talent appears to remain a challenge for organisations, the substantive theory provides a framework for alternative solutions to address this and associated issues. Thirdly, the study offers insights into the external environment and market conditions affecting the flow of talent in organisations and which need to be addressed. Finally, as local research has focused on either talent management in the public sector (Koketso, 2011) or in the private sector (Mathafena, 2015), the study has expanded the existing body of knowledge on local talent management to the construction industry.

\section{Practice}

The practical contribution is fourfold. Firstly, the study offers a framework and useful recommendations for practicing managers, leadership and policymakers that can also be applied in organisations other than in the construction industry. Secondly, it provides guidelines to simplify complex issues, thus optimising talent management. Thirdly, with regard to the external environment, the framework aids competitive advantage by providing insight on best practice talent management and the ways in which organisations may reduce their risk of non-compliance with employment legislation. Finally, the research provides strategic alignment on talent management in the challenging context of globalisation; regulatory frameworks and labour market dynamics as well as issues such as organisational image, diversity and inclusion.

\section{Limitations and future research}

This qualitative approach investigated a single case within the South African construction industry. A single case study does not provide answers to broader issues on talent management in the South African construction industry. More studies are needed to generalise the findings to the broader construction industry in South Africa and other countries. Although the perceptions of people from senior management, middle management and junior management were obtained, the important experiences and views of other level employees were omitted. Future research covering opinions of lower-level employees needs to be explored.

Building on this study, we proposed future research into the following:

- A focus on the areas that evaluate the effectiveness of the talent management practices and return on investment to the construction industry.

- Exploring how talent diversity and intercultural competence can contribute to talent management practices in the global business environment.

- Verifying the impact of transformation imperatives on talent management in the South African context.

\section{Recommendations to management}

Consistent with Mathafena's (2015) study of talent management in the private sector, the findings of this research study showed that the talent management maturity level in the construction industry was relatively low and below expectations. Talent management practitioners in the construction industry should be vigilant and actively engage management in identifying, visibly supporting and providing talent with opportunities for growth. Leadership support is vital in endorsing an enabling environment that cultivates talent and retains a healthy talent resource. Without leadership's utilisation of opportunities to provide an enabling environment, talent is not secured and will not thrive. Without a healthy talent pool, an organisation's success is jeopardised.

\section{Conclusion}

Talent management is at the centre of an organisation's success. When effectively implemented, talent management practices yield positive attitudinal, behavioural and performance outcomes which, in turn, translate into attracting and retaining talent. The proposed talent management framework for the local construction sector offers a pragmatic approach and, if modified and adapted, may be applied to any local construction organisation. The research findings confirmed the significance of meticulous talent management in the construction industry. The effective implementation of the talent management practices may yield both talent attraction and retention. Detailed talent management planning could lead to competitive advantage, supported by an effective financial performance, which secures a sustainable business.

\section{Acknowledgements Competing interests}

The authors declare that they have no financial or personal relationships that may have inappropriately influenced them in writing this article.

\section{Author's contributions}

S.S., W.S. and R.V.W. equally contributed to this article. This article derived from the PhD thesis of S.S. W.S. was the supervisor, and R.V.W. was the co-supervisor of the study.

\section{References}

Aggarwal, U., \& Bhargava, S. (2009). Reviewing the relationship between human resource practices and psychological contract and their impact on employee attitude and behaviours: A conceptual model. Journal of European Industria Training, 33(1), 4-37. https://doi.org/10.1108/03090590910924351

Alkire, T. D. (2014). The attractiveness of emerging market MNCs as employers of European and American talent workers: A multicultural study. Internationa Journal of Emerging Markets, 9(2), 333-370. http://doi.org/10.1108/IJoEM-082012-0091

Bloomberg, L. D., \& Volpe, M. (2008). Completing your qualitative dissertation A roadmap from beginning to end. Los Angeles, CA: Sage.

Bogdan, R., \& Biklen, S. K. (1992). Qualitative research for education: An introduction to theory and methods (3rd edn.). Boston, MA: Allyn \& Bacon.

Böhmer, N., \& Schinnenburg, H. (2016). How gender and career concepts impact global talent management. Employee Relations, 38(1), 73-93. http://doi.org/ 10.1108/ER-07-2015-0154 
Boshard, D., \& Louw, A. (2011). Talent: Trends impacting its availability and what you business should do about it. In I. Boninelli \& T. Meyer (Eds.). Human capital trends: Building a sustainable organisation (pp. 44-58). Randburg: Knowres.

Branthwaite, A., \& Patterson, S. (2011). The power of qualitative research in the era of social media. Qualitative Market Research: An International Journal, 14(4), 430-440. http://doi.org/10.1108/13522751111163245

Bryman, A., \& Bell, E. (2007). Business research methods (2nd edn.). Oxford: Oxford University Press.

Burger, M., Verster, B., \& Zulch, B. (2015). The construction project manager in South Africa: Analysis of industry-specific knowledge. Acta Structilia, 22(1), 48-72.

Bussin, M. (2015). Factors driving changes to remuneration policies in South Africa. South African Journal of Labour Relations, 39(2), 43-63.

Caplan, J. (2014). Thinking differently about talent development. Human Resource Management International Digest, 22(2), 42-45. http://doi.org/10.1108/ HRMID-03-2014-0034

Construction Education Training Authority. (2017). Construction sector education and training authority, a 5 year sector skills plan 2017-2022, CETA SSP, Midrand.

Chew, J., \& Chan, C. (2008). Human resource practices: Organizational commitment and intention to stay. International Journal of Manpower, 29, 503-522. https:// doi.org/10.1108/01437720810904194

Coulson-Thomas, C. (2012). Talent management and building high performance organisations. Industrial and Commercial Training, 44(7), 429-436. http://doi. org/10.1108/00197851211268027

Creswell, J. W. (2003). Research design: Qualitative, quantitative, and mixed methods approaches. London: Sage.

Dhanabhakyam, M., \& Kokilambal, K. (2014). A study on existing talent management practice and its benefits across industries. Impact: International Journal of Research in Business Management, 2(7), 23-36. Retrieved from https://ia802301.us.archive. $\mathrm{org} / 14 /$ items/4.ManageAStudyOnExistingTalentManagementPracticeK.Kokillambal/ 4.\%20Manage-A $\% 20$ Study $\% 20$ on $\% 20$ existing $\% 20$ talent $\% 20$ management $\% 20$ practice-K.\%20Kokillambal.pdf

Downs, L. (2015). Star talent: Investing in high-potential employees for organizational success. Industrial and Commercial Training, 47(7), 349-355. http://doi. org/10.1108/ICT-06-2015-0041

Dubey, R., \& Gunasekaran, A. (2015). Shortage of sustainable supply chain talent: An industrial training framework. Industrial and Commercial Training, 47(2), 86-94. $\mathrm{http}: / /$ doi.org/10.1108/ICT-08-2014-0052

Eilo, W., Yu, Y., Tam, N., \& Loek, L. (2016). The puzzle of Macao's talent development Asian Education and Development Studies, 5(4), 423-437. https://doi. org/10.1108/AEDS-11-2015-0060

Emuze, F., \& Smallwood, J. J. (2014). Collaborative working in South African construction: Contractors' perspectives. Journal of Engineering, Design and Technology, 12(3), 294-306. https://doi.org/10.1108/JEDT-08-2010-0057

Ewerlin, D., \& Süß, S. (2016). Dissemination of talent management in Germany: Myth facade or economic necessity? Personnel Review, 45(1), 142-160. http://doi. org/10.1108/0957409091095486

Fapohunda, J. A. (2014). Evaluation of site managers' hindrances towards optima utilisation of construction resources. Journal of Engineering, Design and Technology, 12(3), 348-363. http://doi.org/10.1108/JEDT-03-2012-0013

Fapohunda, J. A., \& Chileshe, N. (2014). Evaluation of site managers' hindrances towards optimal utilisation of construction resources. Journal of Engineering, Design and Technology, 12(4), 461-474. http://doi.org/10.1108/JEDT-03-2012-0013

Farquhar, D. (2013). NCEA business studies: A workbook @level 2. Auckland: Nelson Cengage Learning.

Guercini, S. (2014). New qualitative research methodologies in management. Management Decision, 52(4), 1. http://doi.org/10.1108/MD-11-2013-0592

Gundling, E., Caldwell, C., \& Cvitkovich, K. (2016). Global talent: Beyond outsourcing. In Advances in global leadership (pp. 353-374). Retrieved from http://doi. org/10.1108/S1535-120320160000009025

Hassanzadeh, M. (2015). Global leadership competencies and training. Journal of Leadership, Accountability and Ethics, 5(2), 137-146. http://doi.org/10.5901/ jesr.2015.v5n2p137

Herbert, B. (2016). Moving employee talent key to competitive edge. Strategic HR Review, 15(2), 65-69. http://doi.org/10.1108/SHR-01-2016-0005

Hirsh, W. (2014). Four steps to effective talent management. Strategic HR Review, 13(3). http://doi.org/10.1108/SHR-01-2014-0009

Hoek, L. V. A. N. (2016). Millennial engineers: Talent management expectations and needs in an African mining corporation. Journal of Contemporary Management, 13, 482-505.

Holt, K., \& Seki, K. (2012). Global leadership: Begins with learning professionals. $T+D$, $66(5), 32-38,6$.

Human Capital and Labour Report. (2017). Johannesburg: Knowledge Resources

INSEAD. (2016). The global talent competitiveness index 2017, Fontainebleau, France. Retrieved from http://www.gtci2017.com/documents/GTCI_2017_web_r5.pdf

Kapoor, B. (2011). Impact of globalization on human resource management, Journal of International Management Studies, 6(1), 1-8.

Kock, R., \& Burke, M. (2008). Managing talent in the South African public service. Public Personnel Management, 37(4), 457-470. http://doi.org/10.1177/00910260080 3700406

Koketso, L. P. (2011). Perceived challenges to talent management in the South African public service: An exploratory study of the city of Cape Town Municipality (M.Tech - Human Resources Management). Unpublished master's dissertation. Cape Peninsula University, Cape Town, South Africa.
Leon, S., \& Uddin, N. (2016). Finding supply chain talent: An outreach strategy. Supply Chain Management: An International Journal, 21(1), 20-44. http://doi. org/10.1108/SCM-02-2015-0084

Liu, Y., \& Pearson, C. A. L. (2014). The importance of talent management: A study of Chinese organisations. Journal of Chinese Economic and Foreign Trade Studies, 7(3), 153-172. http://doi.org/10.1108/JCEFTS-12-2014-0026

Maloa, F., \& Bussin, M. (2016). Determinants of executive compensation in South African state-owned enterprises. South African Journal of Labour Relations, 40(1), 8-24.

Manpower Group. (2013). 2013 Talent shortage survey research results. Retrieved from https://www.manpowergroup.com/wps/wcm/connect/587d2b45-c47a4647-a7c1-e7a74f68fb85/2013_Talent_Shortage_Survey_Results_US_high+res. pdf?MOD=AJPERES

Manpower Group. (2015). 2015 Global talent shortage survey. Retrieved from http:// www.manpowergroup.com/wps/wcm/connect/db23c560-08b6-485f-9bf6f5f38a43c76a/2015_Talent_Shortage_Survey_US-lo_res.pdf?MOD=AJPERES.

Mariampolski, H. (2011). Benefits of qualitative research. In H. Mariampolski (Ed.), Qualitative market research: A comprehensive guide ( $\mathrm{pp} .55-56)$. London: Sage.

Marvasti, A. B. (2011). What is qualitative research? In H. Mariampolski (Ed.), Qualitative market research: A comprehensive guide (pp. 2-14). London: Sage. Retrieved from https://doi.org.helicon.vuw.ac.nz/10.4135/9781849209700.n1

Mathafena, R. B. (2015). A talent management framework for the private sector. Unpublished doctoral dissertation. University of the Free State, Bloemfontein, South Africa.

McGettingan, E., \& O'Neill, D. (2009). From apprentice to construction manager and beyond: Developing a talent pipeline. Education + Training, 51(3), 220-231. http://doi.org/10.1108/00400910910960768

McNulty, Y., \& De Cieri, H. (2016). Linking global mobility and global talent management: The role of ROI. Employee Relations, 38(1), 8-30. http://doi. org/10.1108/ER-08-2015-0157

Meyer, T. (2016). Talent framework and issues in talent management. In T. Meyer (Ed.), Shaping Africa's talent: Enabling Africa's potential. Randburg, South Africa: KR Publishing.

Minneci, F. (2015). If there were a "highly skilled red octopus"? The case of Italian highly skilled mobility at times of crisis. Economics \& Sociology, 8(3), 170-182. http://doi.org/10.14254/2071-789X.2015/8-3/13

Mitchell, M. L. (2011). Private-sector research settings. In M. L. Mitchell (Ed.), Qualitative research methods: Employing qualitative methods in the private sector. Thousand Oaks, CA: Sage.

Ng, E. S., \& Parry, E. (2016). Multigenerational research in human resource management. In M. R. Buckley, J. R. B. Halbesleben, \& A. R. Wheeler (Eds.) Research in personnel and human resources management (vol. 34, pp. 1-41) Bingley, UK: Emerald Group. http://doi.org/ISSN: 0742-7301/doi:10.1108/S0742730120160000034008

Nilsson, S., \& Ellström, P.-E. (2012). Employability and talent management: Challenges for HRD practices. European Journal of Training and Development, 36(1), 26-45. http://doi.org/10.1108/03090591211192610

O'Donnell, H., Karallis, T., \& Sandelands, E. (2008). Reflecting on the skills agenda: A construction industry perspective. Education + Training, 50(1), 59-63. http://doi. org/10.1108/00400910810855522

Oyewobi, L. O., Windapo, A. O., \& James, R. O. B. (2015). An empirical analysis of construction organisations' competitive strategies and performance. Built Environment Project and Asset Management, 5(4), 417-431. http://doi. org/10.1108/BEPAM-10-2013-0045

Ping, T. S. (2011). Impact of talent management practices towards organizational commitment. Penang: Universiti Sains Malaysia.

Price Waterhouse Coopers' Annual Global CEO Survey. (2011). Growth reimagined: Prospects in emerging markets drive CEO confidence. Price Waterhouse Coopers. Retrieved from http://pwc.com

Ramaiah, T. S., \& Raut, R. A. (2014). Talent management practices in corporate world. International Journal of Organisational Behaviour \& Management Perspectives, 3(1), 2279-2950.

Ratten, V., \& Ferreira, J. (2016). Global talent management and corporate entrepreneurship strategy. In V. Ratten, \& J. Ferreira, (Eds.), Global talent management and staffing in MNEs (pp. 151-165). Retrieved from http://doi. management and staffing in MNEs (pp.
$\mathrm{org} / 10.1108 / \mathrm{S} 1876-066 \times 20160000032006$

Rosenthal, R., \& Rosnow, R. L. (2008). Essentials of behavioral research: Methods and data analysis (3rd edn.). New York: McGraw-Hill.

Ruël, J. M. H., \& Lake, C. (2014). Global talent management in MNCs in the digital age: Conceptualizing the GTM-ICT relationship. In T. Bondarouk, M. R. OlivasLuján (Eds.) Human Resource Management, Social Innovation and Technology (pp. 155-178). Bingley: Emerald.

Sahay, P. (2015). The complexity of recruiting. Strategic HR Review, 14(5), 182-187. http://doi.org/10.1108/SHR-04-2015-0034

Sambartolo, M. (2015). Keys to optimising workforce resources across the enterprise. Strategic HR Review, 14(5), 168-173. http://doi.org/10.1108/SHR08-2015-0062

Sawhney, A., Agnihotri, R., \& Paul, V. K. (2014). Grand challenges for the Indian construction industry. Built Environment Project and Asset Management, 4(4), 317-334. http://doi.org/10.1108/BEPAM-10-2013-0055

Senaratne, S., \& Samaraweera, A. (2015). Construction project leadership across the team development process. Built Environment Project and Asset Management, 5(1), 69-88. https://doi.org/10.1108/BEPAM-10-2012-0049 
Shikweni, S. (2010). Performance management: Mining Company A. In A. C. Wilkinson, M. Fourie, A. H. Strydom, L. van der Westhuizen, \& J. van Tonder (Eds.) Performance management of academic staff in South African higher education. Bloemfontein: Centre for Higher Education Studies and Development.

Silvanto, S., \& Ryan, J. (2014). Relocation branding: A strategic framework for attracting talent from abroad. Journal of Global Mobility, 2(1), 102-120. http://doi. org/10.1108/JGM-07-2013-0046

South Africa. (1998). Employment Equity Act, no. 55. Retrieved from http://www. labour.gov.za/DOL/downloads/legislation/acts/employment-equity/eegazette 2015.pdf.

Statistics SA. (2017). Quarterly labour force survey, STATS SA, Pretoria.

Stewart, C. (2016). How diverse is your pipeline? Developing the talent pipeline for women and black and ethnic minority employees. Industrial and Commercial Training, 48(2), 61-66. http://doi.org/10.1108/ICT-09-2015-0059

Swailes, S., \& Blackburn, M. (2016). Employee reactions to talent pool membership. Employee Relations, 38(1), 112-128. http://doi.org/10.1108/ER-02-2015-0030

Swanepoel, B. J., Erasmus, B. J., \& Schenk, H. W. (2003). South African human resource management. Theory \& practice (4th edn.). Juta: Cape Town.
Tarique, I., \& Schuler, R. S. (2012). Global talent management: Literature review, for the Society of Human Resource Management Foundation. Retrieved from https:// $\mathrm{smlr}$ rutgers.edu/sites/default/files/documents/faculty staff docs/Randall\%20 Schuler_GTM\%20SHRM_\%20Report_Final_Oct $\% 2028 \% 2$ C2012_0.pdf

Thunnissen, M., \& Van Arensbergen, P. (2015). A multi-dimensional approach to talent. Personnel Review, 44(2), 182-199. http://doi.org/10.1108/PR-10-20130190

Worrall, L., Harris, K., Stewart, R., Thomas, A., \& McDermott, P. (2010). Barriers to women in the UK construction industry. Engineering, Construction and Architectural Management, 17(3), 268-281. http://doi.org/10.1108/096999 81011038060

Wu, H., \& Patel, C. (2015). Adoption of Anglo-American models of corporate governance and financial reporting in China. In H. Wu, \& C. Patel (Eds.), Studies in managerial and financial accounting (vol. 29, pp. iii). Bingley: Emerald.

Xue, X., Zhang, R., Yang, R., \& Dai, J. (2014). Innovation in construction: A critical review and future research. International Journal of Innovation Science, 6(2), 111-126. https://doi.org/10.1260/1757-2223.6.2.111

Yin, R. K. (2003). Case study research design and methods (3rd edn.). Thousand Oaks, CA: Sage. 